\title{
O DESENVOLVMENTO DO JULGAMENTO MORAL E sUa RELAÇÃo COM aÇões políticas E JURÍDICAS: UMA ILUSTRAÇÃO A PARTIR DO PENSAMENTO DE ARISTÓtELES
}

(The development of moral judgement and its relationship with political and moral actions. An illustration based on Aristotle's thought)

\section{Leonardo Alves Vieira *}

Resumo: $\mathrm{O}$ trabalho procura enfrentar o tema do julgamento moral e sua relação com ações políticas e jurídicas através da filosofia de Aristóteles. De acordo com sua Metafísica da forma e matéria, exploro a interpretação aristotélica da constituição psíco-material do homem, exposta no De anima. Com base nessas considerações iniciais, a "obra do homem" é estudada no horizonte da Ética a Nicômacos. As virtudes éticas e intelectuais formarão o juízo moral do homem, na medida em que ele gradualmente tome posse de sua alma racional, a medida especificamente humana. Embora uma qualidade da alma, o agir moral não pode, contudo, simplesmente negligenciar as circunstâncias corpóreas da vida humana. Finalmente, a Política tematiza o contexto sócio-político-jurídico (as várias formas de constituição e suas bases sócio-econômicas) em que a vida moral alcança seu pleno florescimento ou se defronta com obstáculos que a desviam de sua estrutura racional.

Palavras-Chave: Forma, matéria, homem, ética, política.

Abstract: Taking as a guide Aristotle's philosophy, this paper seeks to address the issue of moral judgement and its relationship with political and juridical

* Doutor em Filosofia pela Universität Gesamthochschule Kassel (Alemanha), professor adjunto do Departamento de Filosofia da Universidade Federal de Minas Gerais (UFMG). Artigo submetido a avaliação no dia 24/08/2009 e aprovado para publicação no dia 05/11/ 2009. 
actions. According to the philosopher's Metaphysics of form and matter, I investigate the Aristotelian idea of the psycho-material constitution of man, as presented in De anima. Based on the above mentioned considerations, "the function of man" is studied within the horizon of the Nicomachean Ethics. Moral and intellectual virtues form man's moral judgement as he gradually gets possession of his rational soul, the human measure par excellence. Although it is a quality of the soul, the moral deed cannot, however, neglect the corporeal condition of human life. Finally, Aristotle's Politics deals with the social, political and juridical context (the several forms of constitution and their socio-economic bases) in which moral life reaches its full unfolding or faces obstacles that deviate it from its rational structure.

Keywords: form, matter, man, ethics, politics

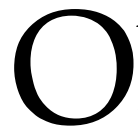
tema do desenvolvimento do julgamento moral e sua relação com ações políticas e jurídicas compreendem uma área vastíssima. Dois textos, sem intenção de esgotar a bibliografia sobre o tema, podem nos dar a medida de sua amplitude. Bobbio (1985) discute o mundo político-jurídico tal como enquadrado nas diferentes formas de governo, de Platão a Marx. Em uma perspectiva histórico-teórica, as teorias das formas de governo deixam entrever, ora explicitamente, ora implicitamente, como o agir moral encontra seus condicionantes na estrutura política proporcionada por uma determinada forma de governo.

Kersting (1994) investiga, por sua vez, a filosofia política do contrato social, desde o início do século XVII até a época contemporânea. Também de forma mais ou menos clara e desenvolvida, as condicionantes ao agir moral impostas pelos modelos das teorias do contrato social são apresentadas tanto em sua diferenciação do modelo aristotélico quanto na crítica ao paradigma do modelo do contrato social por Hume, Hegel e pelos Burkeanos.

Em uma perspectiva que inclui, mas também vai além do vínculo do desenvolvimento moral com as ações políticas e jurídicas, pode ser também aludido o trabalho de Wilber (1999). Esse autor acompanha o desenvolvimento moral desde seu início, a moral pré-convencional, passando pela moral convencional e pós-convencional, até sua realização como moral pós-pós-convencional ${ }^{1}$. Os estudos de Wilber contemplam a linha de desenvolvimento moral e as perspectivas por ela entreabertas para os mais diversos tipos de ação: cognitiva, moral, estética, afetiva, etc. Seu texto levanta, aliás, a seguinte pergunta, embora não respondida aqui, nesse trabalho, em virtude das limitações impostas pela dinâmica de debate

${ }^{1}$ Vd., entre outros textos de WILBER, Integral Psychology (1999). 
adotada por esse congresso ${ }^{2}$ : a tematização do ethos promovida por Aristóteles, objeto de estudo desse artigo, permanece prisioneira dos limites de uma moral convencional ou abrange também a moral pós-convencional ou mesmo a pós-pós-convencional?

Seja lá como for, não será possível tratar do objeto em questão na complexidade que ele merece. Por isso, limitar-me-ei à filosofia de Aristóteles. A escolha por Aristóteles reside na sua enorme influência ao longo do pensamento ocidental e por sua posição de alternativa ao modelo contratualista implantado na época moderna. Pois, os críticos ao modelo contratualista recorrerão a certas teses de Aristóteles para contrabalançar os aspectos negativos daquele modelo, embora meu objetivo, nos limites desse trabalho, não seja explorar as diferenças entre eles, bem como não tenciono fazer uma defesa do modelo aristotélico contra o paradigma contratualista ou qualquer outro. Meu propósito, de acordo com a proposta do congresso, é articular, pelo menos em suas linhas gerais, os domínios do ético e do político no que tange ao desenvolvimento do indivíduo que se lança a atividades na esfera pública, tomando como fio condutor a filosofia de Aristóteles.

O estudo dessa questão em Aristóteles envolve, então, uma articulação entre seus textos que lidam com metafísica, psicologia, ética e política. No âmbito da Metafísica e do De Anima serão investigadas as condições ônticas que permitem pensar a estrutura composta constitutiva do ser humano (I). Depois disso, a investigação caminhará para o estudo do ethos humano individual na Ética a Nicômacos, tal como ele pode ser vinculado com aquelas condições e aquela estrutura (II e III). Finalmente, algumas implicações políticas do contexto formado por metafísica, psicologia e ética serão debatidas tendo em vista o desenvolvimento do juízo moral na esfera político-jurídica, levando em conta seu livro sobre a Política (IV e V).

O julgamento moral aqui investigado não diz respeito à lógica ínsita à construção de juízos morais, como poder-se-ia inicialmente pensar. Portanto, não se trata de um estudo sobre conceitos, juízos e silogismos da verdade prático-moral. O julgamento moral é interpretado, diferentemente, como o horizonte ético entreaberto pela ação moral assumida pelo indivíduo à medida que ele toma posse da integralidade do seu ser (corpo e almas vegetativa, sensitiva e racional). Ele avalia, então, sua própria expe-

\footnotetext{
${ }^{2}$ Esse trabalho foi apresentado e discutido no congresso Novas visões sobre democracia e moralidade no contexto global: um diálogo acadêmico-político entre culturas a respeito de justiça, soberania e intervencionismo ecológico, no período de 26 a 28 de agosto de 2008 na Faculdade de Direito da Universidade Federal de Minas Gerais. Participei do debate $O$ desenvolvimento do julgamento moral e sua relação com ações políticas e jurídicas, no dia 28 de agosto de 2008. Ele foi levemente modificado tendo em vista a interação com o público presente, ao qual sou muito grato pelas questões a mim dirigidas.
} 
riência individual, bem como aquela de sua comunidade de acordo com aquele horizonte. Mas, esse horizonte, por sua vez, como bem observou Aristóteles, encontra-se também em estreita interação com o contexto sócio-político-jurídico de sua vida, de tal forma que o julgamento moral não é imune a este contexto. À forma do julgamento moral do indivíduo em sua interação com o contexto sócio-político-jurídico de sua prática ética está dedicada a investigação que se segue.

O julgamento moral em Aristóteles guarda um estreito vínculo com a questão relativa ao homem ( $(\alpha) \rho \rho \omega \pi)$ ). A questão relativa ao homem, por sua vez, abre as portas para a compreensão do seu ethos, seja no âmbito individual, seja na dimensão político-jurídica. Ao conhecer o que é o homem pode, então, ser desenvolvida uma teoria sobre as ações que caracterizam a práxis humana.

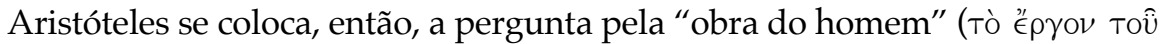
à $\nu \rho\left(\omega \dot{\pi} v^{3}\right)$ : qual é a atividade caracteristicamente humana? Ora, para conhecer a obra especificamente humana é, portanto, necessário entender o que é o homem em sua estrutura ôntica. Isto requer, por sua vez, articular as reflexões de sua Metafísica com aquelas do De anima.

O homem é substância (oujsiva) no sentido de um sínolo, substância com-

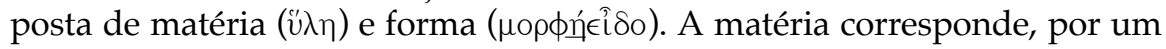
lado, à potência e ao corpo, ao passo que a forma diz respeito, por outro lado, ao ato e à alma ${ }^{4}$. O homem é, portanto, a matéria organizada e posta na condição de ser o corpo de um ser humano em razão da forma. A forma do homem enforma a matéria, de tal modo que esta recebe uma configuração conforme àquela. Ora, a matéria pode ser uma expressão da forma humana, a saber, o corpo próprio ao homem, já que a matéria é o que, em potência, guarda em si a vida, atualizada, no entanto, pela alma: "a alma é substância

${ }^{3}$ ARISTÓTELES, Ethica Nicomachea, 1097 b 24 - 25. As traduções dos textos de Aristóteles são de minha responsabilidade, salvo indicação em contrário.

${ }^{4}$ No início do Livro II, Capítulo 1 do De anima, Aristóteles retoma sucintamente sua teoria sobre a substância: como matéria, como forma e como composição entre matéria e forma; vd. também a tradução do De Anima, com apresentação e notas de Maria Cecília Gomes dos Reis; vd., entre outras passagens, Metafísica, 1028 b 33 - 1029 b 12, principalmente, 1029 a 26 - 30; para um resumo dessa teoria, vd. REALE, (2001), p. 87 - 109; REALE (1994), p. 352 - 58. Ainda sobre ética e ontologia em Aristóteles, vd. ZINGANO, M. (1996 e 1998). 
como forma do corpo natural que, em potência, tem a vida" ${ }^{5}$. Portanto, sem a participação do ato formador da alma, a vida potencial do corpo não pode ser levada a efeito.

Em termos concretos, isto significa que a alma vegetativa, por exemplo, uma das formas constitutivas da forma humana, é responsável pela geração, nutrição, reprodução e pelo crescimento dos seres vivos. Assim sendo, a natureza somente - o corpo natural apenas - não levaria a cabo todas essas atividades sem a participação da alma que traz à atividade as potências nutritiva, reprodutiva, etc ${ }^{6}$. "Todo corpo natural participante da vida" é "substância composta"7, porque ele é animado por uma forma que o faz ser o que é. Não diferente é o corpo humano, o qual é justamente humano, porque o anima uma forma tipicamente humana. Enfim, a alma é o que

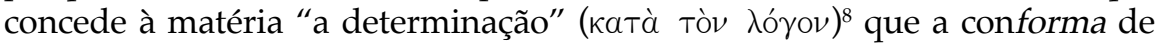
acordo com um corpo tipicamente humano e lhe proporciona a medida humana.

A forma humana não é, todavia, simples, mas complexa. Ela possui uma parte irracional e uma racional. Ambas são, por sua vez, duplas. A parte irracional é composta pela alma vegetativa e alma sensitiva. A primeira é, por natureza, irracional, estando, portanto, subtraída ao comando da razão. A segunda é responsável por sensações, apetites e movimento e é também, por natureza, irracional, como a primeira. Diferentemente desta, no entanto, a alma sensitiva pode tornar-se obediente aos reclamos da razão - de modo análogo à convicção de obediência que um filho pode ter diante do seu pai -, de tal modo que ela é irracional por natureza, por um lado, e racional por participação, por outro?.

Até o momento, no entanto, não há uma especificidade da forma humana, já que a alma vegetativa e a alma sensitiva são comuns a outros seres além dos humanos. A forma humana específica tem lugar na alma racional: o âmbito do discurso racional e demonstrativo e da intuição dos primeiros princípios. Em razão disso, a obra tipicamente humana tem de estar "ali" "onde" a forma racional estiver presente. Isto não quer dizer, evidentemente,

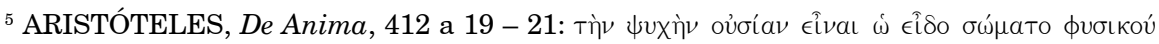

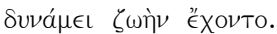

${ }^{6}$ ARISTÓTELES, De Anima, 415 a 22 - 415 b 21.

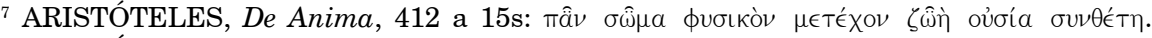
8 ARISTÓTELES, De Anima, 412 b 10s.

${ }^{9}$ ARISTÓTELES, Ethica Nicomachea, 1097 b 22 - 1098 a 20; 1102 b 13 - 1103 a 3; a interpretação clássica é de Gauthier e Jolif (1970).
} 
que as ações em que a alma vegetativa estiver presente não sejam mais ações humanas. Afinal, se a forma humana inclui a alma vegetativa, o homem não pode ser entendido sem a forma vegetativa. Na medida, contudo, em que o que distingue o homem de outros seres é a alma racional, ela assinala uma atividade que é unicamente humana.

Com isso, então, o caráter duplo da forma racional humana é constituído pela alma sensitiva, enquanto obedece à razão, e pela alma racional. A alma sensitiva desempenha, assim, um papel mediador entre as dimensões irracional e racional da alma e desempenhará, como veremos, um papel fundamental na formação da virtude moral.

A felicidade ( $\epsilon \dot{\delta} \delta a \iota \mu o v i ́ a)$ é "o mais alto de todos os bens praticáveis"10. Na determinação desse bem, ele analisa, inicialmente por meio da exclusão, os tipos de vida que nos parecem dar a felicidade suprema, mas que, por assim dizer, não passam no teste, porque não correspondem ao que há de

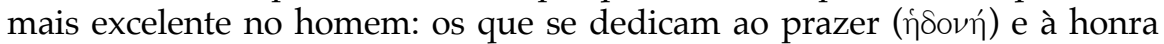

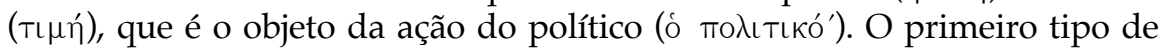
vida nos aproximaria dos animais e não mostraria o que é especificamente humano, pois nos nivelaria ao que corresponde, por assim dizer, a " $2 / 3$ " da forma humana: alma vegetativa e sensitiva; neste sentido, seríamos "humanos de $2 / 3$ ", se pudéssemos traduzir quantitativamente a forma humana. Isto não significa, contudo, que a atividade da alma racional não tenha um prazer que lhe é próprio e peculiar ${ }^{11}$, mas, sim, que o prazer proporcionado pelas almas vegetativa e sensitiva não oferece o deleite propriamente e especificamente humano.

O segundo tipo depende de quem a concede, diminuindo ou, no extremo, eliminando as ações meritórias que devem qualificar o homem como um ser feliz. Assim sendo, elas não podem proporcionar o bem supremo do homem. A riqueza, por sua vez, não merece ser contada entre aquilo que deve constituir o sentido último da vida humana, pois é vivida sob compulsão e destinada a algo mais além da própria atividade da obtenção

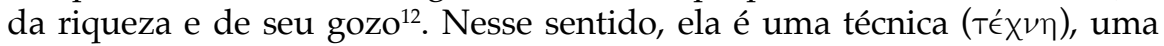

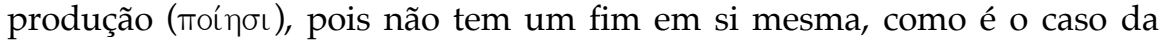
praxis $\left(\pi \rho \hat{a ̂} \xi_{\iota}\right)$ em que a ação também é a finalidade da ação ${ }^{13}$.

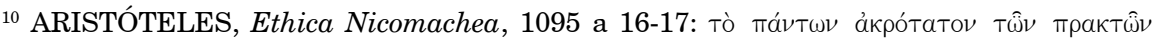
ảyatóv.

11 ARISTÓTELES, Ethica Nicomachea, 1177 b 15 - b 25.

12 ARISTÓTELES, Ethica Nicomachea, 1095 b 5 - 1096 a 9.

13 ARISTÓTELES, Ethica Nicomachea, 1094 a 1 - 29.
} 
Assim como o ser pode ser dito de vários modos, o bem é também dito de vários $\operatorname{modos}^{14}$. A busca pelo bem deve, portanto, levar em contar a multiplicidade de bens; não existe, portanto, uma única forma de bem, tal como ele critica essa tese em Platão, mas uma diversidade de bens.

A felicidade, como bem supremo do homem, pode ser determinada mediante o estudo da obra ou tarefa própria e específica do homem. Ela é interpretada por Aristóteles como "atividade da alma de acordo com a excelência, e se há múltiplas excelências, de conformidade com a melhor e mais completa"15. Embora a felicidade seja uma atividade da alma e não do corpo, já que a felicidade tem de representar a forma humana (a virtude

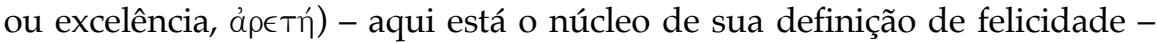
Aristóteles não negligencia, contudo, tendo em vista a realização da felici-

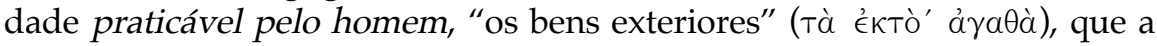
"boa sorte" (єن่TuXía) pode lhe conceder, tais como: amigos, riqueza, poder político, boa estirpe, bons filhos e beleza física ${ }^{16}$. A própria situação ôntica do homem, como um sínolo ou composto de forma e matéria, alma e corpo, exige levar em conta também sua condição corpórea e circunstâncias a ela afeitas, mesmo que a virtude seja, rigorosamente falando, uma qualidade da forma, portanto, da alma. Seu desenvolvimento moral é, pois, afetado por suas condições materiais, podendo, inclusive, minar sua vida virtuosa ${ }^{17}$, e daí derivando, também, a razão da identificação da felicidade ora com a virtude, o mérito formador da felicidade, ora com a boa sorte, com circunstâncias materiais adventícias que escapam ao controle do homem que busca a felicidade ${ }^{18}$. A atenção a essas condições do ato formador da alma na realização moral do homem também estará presente por ocasião de sua investigação da comunidade política e da ação que aí se desenvolve, pois vícios e virtude morais, portanto, julgamentos morais delas resultantes, não estarão imunes às condições materiais que se encontram em torno a suas ações e também são resultados das interações com elas.

A posição de Aristóteles a respeito da virtude como propriedade da alma e sua posição acerca do corpo como elemento que não deve ser descurado na vida moral deixa transparecer a revolução feita por Sócrates no âmbito da sociedade grega. A cultura grega em cujo seio viveu Sócrates valorizava a beleza do corpo físico e o poder do indivíduo em vencer seus adversários nas batalhas e em amealhar riquezas, ao passo que Sócrates acentua a

\footnotetext{
${ }^{14}$ ARISTÓTELES, Ethica Nicomachea, 1096 a 6; Metafísica, 1033 a 33: Tò Sé ôv $\lambda \hat{\gamma} \gamma \in$ Tal

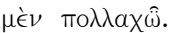

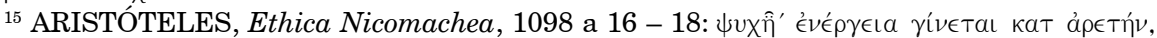

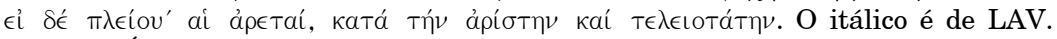

${ }^{16}$ ARISTÓTELES, Ethica Nicomachea, 1099 a 31 - 1099 b 6.

17 ARISTÓTELES, Ethica Nicomachea, 1100 b $22-1101$ a 17.

${ }^{18}$ ARISTÓTELES, Ethica Nicomachea, 1099 b 6 - 8 .
} 
primazia da beleza da alma e da vitória sobre si mesmo ${ }^{19}$. Nesse sentido, a posição de Aristóteles, embora esteja no caminho aberto por Sócrates, não deixa também de conceder as devidas razões ao seu contexto sóciocultural, buscando uma forma de conciliar o novo e o antigo.

Aristóteles distingue dois tipos de virtude ou excelência: a ética ou moral e a intelectual ou dianoética. Elas podem ser esquematizadas do seguinte $\operatorname{modo}^{20}$ :

\begin{tabular}{|c|c|}
\hline 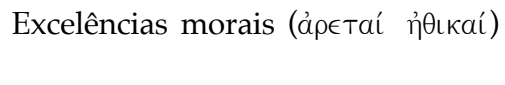 & 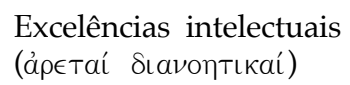 \\
\hline Alma sensitiva + alma racional & Alma racional \\
\hline
\end{tabular}

A virtude moral é formada pelo encontro entre a alma sensitiva e a alma racional. A alma sensitiva é irracional, por natureza, podendo variar para os extremos do excesso ( $(\pi \epsilon \rho \beta O \lambda \eta ́)$ e da carência ( $\left.\epsilon^{\prime \prime} \lambda \lambda \epsilon \iota \psi \iota \iota\right)$. Enquanto a deficiência moral significa uma ação em que o indivíduo erra por excesso ou

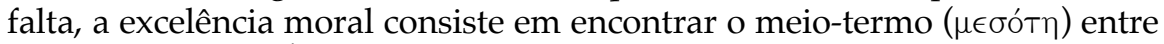
esses extremos ${ }^{21}$. É importante ressaltar que o meio-termo é aquele que é para nós, ao invés de ser um meio-termo absoluto. Trata-se, portanto, de um meio-termo que diz respeito às circunstâncias específicas de cada individuo. Assim é o caso, por exemplo, com o prazer: deficiência e excesso no sentir o prazer assinalam um ethos não mais compatível com a medida da razão. A criança e o jovem são propícios a incorrer nesse tipo de erro, uma vez que o exercício determinante da razão ainda é imaturo. Daí que seu julgamento moral é ainda muito deficiente tendo em vista encontrar a excelência moral. A virtude ética é, portanto, "uma disposição

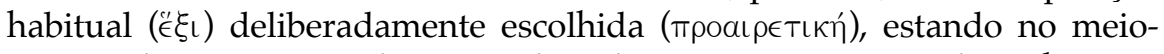
termo relativo a nós e determinado pela razão, graças à qual um homem dotado de discernimento o determinaria" ${ }^{\prime 22}$.

O desenvolvimento do julgamento moral não ocorre automaticamente com o simples avançar da idade. Uma pessoa idosa não é, pelo simples fato de ter mais idade, uma pessoa virtuosa. Pois, se esse fosse o caso, toda pessoa idosa seria imediatamente portadora de excelência moral. A virtude moral

${ }^{19}$ REALE (1993), p. $254-287$.

20 ARISTÓTELES, Ethica Nicomachea, 1103 a 3 - 10.

${ }^{21}$ WOLF (1995), p. 92s, vê na produção, na técnica, a origem da tese do meio-termo, o qual, posteriormente, é "aplicado" no âmbito da ação, da práxis.

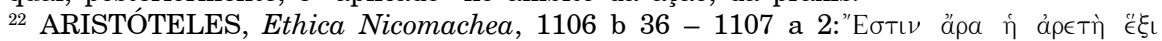

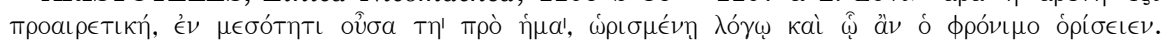


não é alcançada pelo simples acúmulo quantitativo de anos. A importância desse quantitativo reside no fato de que ele proporciona as experiências necessárias para que o exercício da razão sobre afecções e ações da alma sensitiva tenha lugar. É necessária, portanto, uma educação, uma paideiva dos afetos, para que a justa medida possa ser encontrada. Ora, essa justa medida é a obra por excelência do homem, já que ela expressa sua forma específica, a forma racional que lhe é própria no âmbito de sua vida afetiva e apetitiva. A virtude moral é, portanto, a configuração da matéria sensitiva pelo ato determinante da alma racional: o logos é a medida da virtude. A excelência moral significa, portanto, civilização ou cultura de nossos afetos e apetites, para que eles estejam sob o ato judicativo da razão e a ela obedeçam ${ }^{23}$.

A excelência ou virtude dianoética ou intelectual diz respeito, por seu turno, somente à alma racional. A alma racional é divida, por sua vez, em

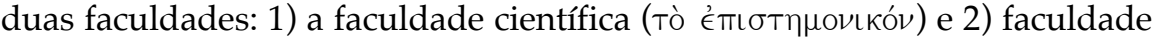

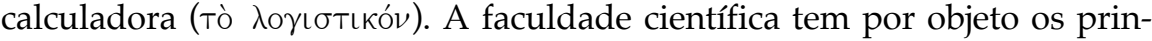
cípios invariáveis, enquanto a faculdade calculadora tematiza as coisas passíveis de variação ${ }^{24}$. Ambas as faculdades são uma disposição habitual $\left(\epsilon^{\prime} \xi \iota\right)$, assim como o é a virtude moral. Diferentemente desta, contudo, que é o meio-termo entre extremos, aquelas faculdades lidam com a verdade: a primeira, com a verdade teórica, ao passo que a segunda tem por objeto

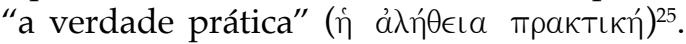

A prudência ou discernimento ( $\phi \rho o ́ v \eta \sigma \iota)$ é a excelência no exercício da faculdade calculadora, pois ela (ele) consiste em escolher corretamente sobre os meios adequados para alcançar os fins expressos pelas excelências morais. Portanto, a excelência moral, "disposição habitual deliberadamente esco-

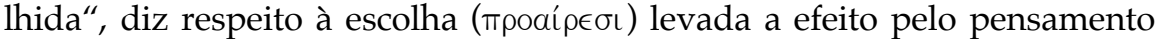
calculador $^{26}$ - alma racional - e pelo desejo (ö $\left.\rho \in \xi_{\iota}\right)$ - alma sensitiva. A escolha é, com efeito, a justa articulação do pensamento verdadeiro com o desejo correto, de tal forma que a afirmação do pensamento e a busca do desejo se direcionem às mesmas coisas: os meios adequados para os fins $\operatorname{corretos}^{27}$. Enquanto envolve a escolha e não é um automatismo natural, a

\footnotetext{
${ }^{23}$ Para uma descrição geral das virtudes éticas, sem levar em conta a virtude da justiça, vd. ARISTÓTELES, Ethica Nicomachea, 1107 a 34 - 1108 b 16; sobre as características de uma moral convencional presentes nas virtudes éticas descritas por Aristóteles, vc. Wolf (1995), p. 93.

${ }^{24}$ ARISTÓTELES, Ethica Nicomachea, Livro VI, Cap. I.

${ }^{25}$ ARISTÓTELES, Ethica Nicomachea, 1139 a 26s.

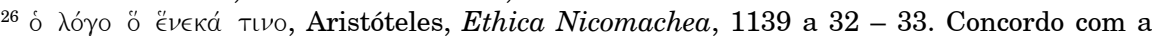
tradução de GAUTHIER e JOLIF (1970), p. 444 (Tome II, Deuxième Partie; Commentaires, Livres VI - X ): "pensamento calculador", ao passo que Mário Kury traduz como "raciocínio dirigido a algum fim”. Aristóteles. Ética a Nicômacos, trad. Mário Kury (1992), p. 114.

${ }^{27}$ ARISTÓTELES, Ethica Nicomachea, 1130 a 23 - 27.
} 


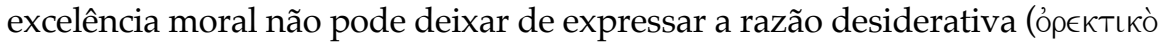

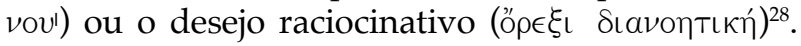

A virtude moral faz parte da "obra humana", aquela em que o especificamente humano é ressaltado. Ora, qual é a "obra humana" quando a excelência ética está em jogo e a virtude do discernimento é chamada a atuar,

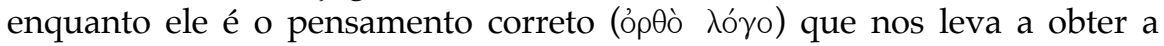
excelência moral ${ }^{29}$ ? "A obra humana (Tò $€ ́ \rho \gamma o \nu$ ) realiza-se de acordo com o discernimento e a excelência moral, porquanto esta torna retos os fins, ao passo que aquele faz retos os meios" ${ }^{\prime 30}$. Existe, pois, uma ligação entre as excelências morais e a virtude intelectual da faculdade calculadora: 1) para ser virtuoso é necessário possuir o discernimento, mas 2) para possuir o discernimento é necessário ser virtuoso ${ }^{31}$.

1) A excelência moral é a justa medida entre os extremos do excesso e da carência; ora, essa justa medida não pode ser determinada sem o concurso do discernimento, já que ele determina o que o indivíduo deve fazer, uma

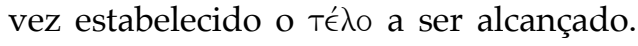

2) O discernimento seria astúcia ou esperteza se ele não fosse a determinação de meios adequados para fins corretos, fins indicados pelas excelências morais. Assim, o malfeitor que conseguiu realizar o fim de sua ação, conseguiu, de fato, agenciar adequadamente os meios para obter o que ele buscava. A escolha desses meios, no entanto, não pode ser obra de um excelente exercício da faculdade calculadora, portanto, não é a virtude do discernimento, já que ele deseja um té $\mathrm{o}$ errado. O concupiscente - a pessoa que deseja o prazer além da justa medida, portanto, em excesso deseja a coisa errada e, portanto, não pode mais ser portador do discernimento, pois não é capaz de identificar os meios apropriados para os fins corretos. Diferentemente do moderado ou temperado, cujo objeto é o prazer na medida certa para suas circunstâncias, o qual faz um uso virtuoso da faculdade calculadora, pois ele identificou as experiências mediadoras que o levaram à vivência correta do prazer. Com efeito, um desejo errado não legitima o desempenho virtuoso da faculdade calculadora por ocasião de sua operação bem sucedida, pois o cálculo bem feito não legitima por si só sua grandeza ética. Portanto, o sucesso não sinaliza imediatamente e necessariamente uma excelente performance ética.

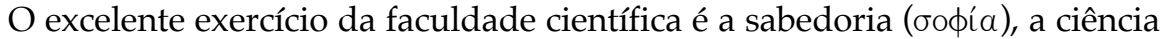
perfeita, pois ela inclui tanto o conhecimento a partir dos princípios (ciência e seu procedimento silogístico, є̇ próprios princípios (inteligência e seu procedimento de captação intuitiva

28 ARISTÓTELES, Ethica Nicomachea, 1139 b 4 - 5.

29 ARISTÓTELES, Ethica Nicomachea, 1144 b 1 - 30.

${ }^{30}$ ARISTÓTELES, Ethica Nicomachea,1144 a 6 - 9.

31 ARISTÓTELES, Ethica Nicomachea, 1144 b 30-32; sobre o círculo aí envolvido vd. WOLF (1995), p. 91s. 
dos próprios princípios, voû). A sabedoria é, de fato, "o conhecimento científico consumado das coisas mais sublimes" ${ }^{32}$.

Ela é a Metafísica, filosofia primeira, a mais elevada das ciências teóricas, pois ela tem por objeto, em sua expressão suprema, o ato puro, a forma pura. Ela tem por objetos, pois, aqueles que estão além do homem, ao passo que o discernimento ainda se ocupa com o homem - o homem que "não é o melhor dos seres existentes no universo"33, já que há "muitas outras coisas mais divinas, por natureza, do que o homem, por exemplo, entre as mais visíveis, os corpos [estrelas e planetas, LAV] dos quais o universo está constituído" ${ }^{34}$ - bem como ele também lida com o que nele e em suas circunstâncias é mutável. A sabedoria, a excelente performance da faculdade científica, nos (e)leva ao máximo de felicidade praticável pelo homem. Ela nos faz, portanto, vivenciar tanto o que é especificamente humano e o algo divino ( $\theta \in \hat{i} o ́ v ~ T l)^{35}$ em nós - a vida do intelecto, aquilo que nos distingue e caracteriza no composto ( $\sigma u ́ \nu \theta \in T O \nu)^{36}$ que é o homem quanto as coisas mais divinas fora de nós ${ }^{37}$.

Tanto a excelência moral quanto a excelência intelectual registram a virtuosa atuação da alma racional e sua determinação da práxis de acordo com um talhe especificamente humano. Elas também mostram que o juízo moral não é algo natural, bem como não é contra a natureza, mas "artificial", resultado de educação e aprimoramento do que nos dá a natureza: a alma e suas faculdades ${ }^{38}$. Para tanto, o indivíduo deve, por assim dizer, tomar posse da alma racional. O juízo moral pressupõe, portanto, a "entrada em cena" da alma racional, de tal forma que sua ação judicativa possa, de fato, acontecer. $\mathrm{O}$ ator ético e o estudioso da ética, da ciência do ethos, não podem, com efeito, prescindir desse vir à cena da alma racional, pois só ela é capaz de juízo moral, independentemente da qualidade virtuosa ou deficiente desse juízo.

A sabedoria é, de fato, a forma suprema do agir moral. O homem, contudo, convive com seus concidadãos na comunidade política e compartilha com eles a sorte dessa comunidade. Por isso, como seu membro, sua vida moral não é imune ao contexto sócio-político em que vive. Por isso, tornase necessário investigar em que medida ele também participa na configuração de sua ação ética ${ }^{39}$.

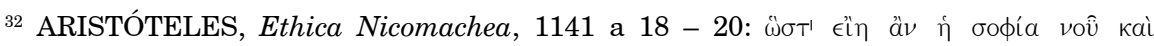

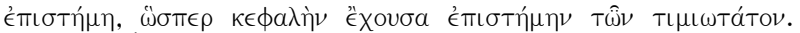

${ }^{33}$ ARISTÓTELES, Ethica Nicomachea, 1140 a 34 - 1141 b 1.

${ }^{34}$ ARISTÓTELES, Ethica Nicomachea, 1140 a 34 - 1141 b 2.

35 ARISTÓTELES, Ethica Nicomachea, 1177 b 28.

${ }^{36}$ ARISTÓTELES, Ethica Nicomachea, 1177 b $28-29$.

37 ARISTÓTELES, Ethica Nicomachea, 1177 b 7 - 1178 a 7.

38 ARISTÓTELES, Ethica Nicomachea, 1103 a 23-26.

${ }^{39}$ Para uma discussão em torno das formas de vida política e teórica, vd. KULLMANN (1995), p. $253-276$.
} 
A passagem da esfera individual para a esfera pública tem lugar, porque (1) o bem do indivíduo e o bem do Estado são o mesmo ${ }^{40}$, a saber, a vida feliz e digna ao ser humano, e porque (2) a vida virtuosa a ser proporcionada pelo Estado é o tipo de vida mais apropriado ao animal político que é o homem.

"O homem é, por natureza, um animal político" ${ }^{41}$. A forma comunitária suprema de existência humana é o Estado, no qual a racionalidade do homem, sua capacidade de comunicação e a excelência de sua ação ganham pleno sentido. Não é por acaso que ele é interpretado por Aristóteles como a comunidade política que existe "em razão do bem viver" ${ }^{42}$. Ele é, portanto, a atualização ética do potencial político-comunitário ínsito ao ser humano, de tal forma que a evolução de seu julgamento ético-político encontra nele seu locus "natural" de efetivação: "natural", porque o Estado é o télos coletivo imanente à forma humana específica, à forma racional.

A passagem da vida ética individual para a vida ética pública é mediatizada pela família (ô̂́o) e vila $(\kappa \omega ́ \mu \eta)^{43}$. Ambas não conseguem efetivar a exigência do agir ético, porque a primeira, dirigida para a geração de novos membros da comunidade e satisfação das necessidades materiais básicas, não consegue bastar a si mesma, e porque a segunda, embora efetive, de uma forma melhor do que a família, a satisfação das carências materiais fundamentais da existência, não é capaz também de oferecer a realização moral e espiritual proporcionada pelo Estado como atualização da liberdade entre os humanos. Embora cronologicamente posterior à família e à vila, o Estado é ontologicamente anterior a ambas, pois é o todo que confere sentido às partes. Sem ele, o homem não alcançaria sua finalidade imanente e permaneceria perdido em seu agir moral, já que não teria efetivado sua razão de ser ético:

A comunidade instituída, por natureza, para as carências diárias é a família ... A primeira comunidade oriunda de muitas famílias, não em razão de carências diárias, é a vila ... A comunidade perfeita oriunda de muitas vilas é a cidade-Estado (mó $\lambda$ ) ... surgida em razão do viver e subsistindo em virtude do bem viver ${ }^{44}$.

Aproveitando uma articulação com a antropologia aristotélica, a família e a vila desempenham na vida coletiva um papel análogo àquele que as

40 ARISTÓTELES, Ethica Nicomachea, 1094 b 7 - 9.

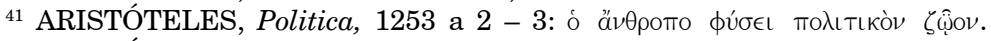

42 ARISTÓTELES, Politica, 1252 b 30.

${ }^{43}$ ARISTÓTELES, Politica, 1252 b 12 - 16.

${ }^{44}$ ARISTÓTELES, Politica, 1252 b 12 - 30. 
almas vegetativa e sensitiva desempenham na constituição da forma humana, ao passo que o Estado (a cidade-Estado) é o análogo político da alma racional. Nesse sentido, sua exigência ético-política não pode ficar aquém da comunidade política, pois, então, "a obra do homem" não estaria consumada, assim como sua exigência ético-espiritual não pode prescindir da alma racional.

Também analogamente à estrutura tripartite da alma, segundo a qual a alma racional comanda a alma sensitiva, a ordem política não pode estar estruturada de acordo com a lógica da esfera familiar. Esta é a ordem do senhor de família, a saber, do déspota ${ }^{45}$, com base em uma relação assimétrica entre seus membros: o déspota, de um lado, mulher, criança e escravos, de outro, ao passo que a ordem política tem como base uma relação entre iguais. Além disso, a ordem política é também ameaçada quando a lógica econômica da família conquista a lógica da política, pois, então, o ritmo da produção e técnica assume a lógica de ação do Estado: ele deixa de ser o topos de realização do homem, segundo a racionalidade da práxis, para ser um instrumento de algo alheio a ele, segundo a racionalidade da produção ${ }^{46}$. Se riqueza não constitui a meta de nossa felicidade no plano individual, a economia, entendida como a lei que rege indivíduos e bens da família, não pode, consequentemente, tornar-se a lei da polis, pois, então, isto implicaria na submissão do toda à parte, da práxis à poiesis.

A invasão da lógica política pelas leis vigentes no oikos, com a conseqüente desfiguração da vida política, constituiria o contraexemplo político-moral da descaracterização da vida moral individual, em que a alma racional tornar-se-ia governada pela alma sensitiva. A inversão da ordem ética individual e política acarreta inevitavelmente uma distorção do julgamento moral. Pois, no caso da vida ética individual, o especificamente humano estaria submetido à vida animal, ao passo que, no caso da vida ética coletiva, a lógica do privado e assimétrico tomaria de assalto a esfera pública: a ruína de um sadio desenvolvimento de nosso juízo moral no que diz respeito à coordenação de ações no mundo da polis ${ }^{47}$.

\footnotetext{
45 ARISTÓTELES, Politica, 1251 b 1 - 14.

${ }^{46}$ Daí, com efeito, a oposição entre o modelo aristotélico e a teoria do contrato social, vd. KERSTING (1994), p. 3s. A questão da submissão da lei da polis à lei da família (oikos + nomos) transparece no mundo moderno como conflito entre o Estado e a sociedade civil - sociedade civil inexistente no mundo greco-medieval e ocupando uma posição intermediária entre o Estado e a família, posição até então assumida pela vila. Em outra publicação, tive a oportunidade de explorar este conflito, tal como discutido em Linhas Fundamentais da Filosofia do Direito (1821) de Hegel: Vieira (1996), p. 157 - 193. Vd. HEGEL, Grundlinien der Philosophie des Rechts, §§ 187; 255; 256, Anm; 262; 308, Anm. ${ }^{47}$ Platão já havia mostrado o vínculo entre as almas racional, passional e apetitiva com as diferentes formas de governo, vd. BOBBIO (1980), p. 43s.
} 
A classificação das constituições políticas também não pode deixar tanto de levar em conta a atualização da racionalidade moral ínsita à forma humana quanto de indicar como o desenvolvimento do juízo moral pode ser favorecido ou desfavorecido por elas. Assim sendo, a "constituição ( poder soberano" ${ }^{\prime 48}$. Ora, a constituição assume várias formas, estabelecendo, com isso, as várias formas de organização da comunidade política. Elas são estruturadas de acordo com a quantidade - quantos detêm o poder político - e a qualidade - como o poder político é exercido, de tal modo que elas condicionam o agir moral nas comunidades políticas:

"Já que a constituição e o ato de governar significam a mesma coisa, e ele é o poder supremo dos Estados, então, ele é necessariamente o de um, o de poucos e o de muitos. Quando um ou poucos ou muitos governam em benefício do interesse comum, essas constituições são necessariamente corretas. Quando as constituições são exercidas em prol dos interesses privados de um, poucos ou muitos, então, ocorrem desvios ${ }^{49}$.

Assim sendo, quando a ordem do privado e assimétrico sequestra a ordem do político, a distorção do julgamento moral permeia a integralidade da esfera política, de tal forma que o interesse comum ( posto e preservado pelo Estado é desviado em favor da lógica posta a

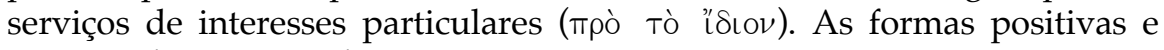
corretas do governo de um, poucos e muitos são, repectivamente, o reino

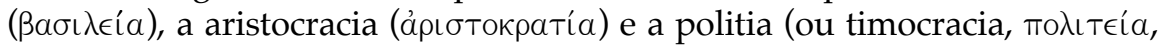
тцнократі́), ao passo que as formas negativas e corrompidas são a tirania

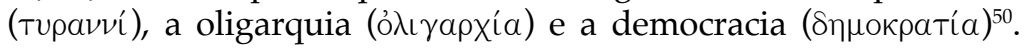

Há também uma hierarquia na degeneração dessas formas de constituição. Se a melhor é o reino, pois a preside um homem excepcional, a degeneração suprema encontra-se na forma corrupta correspondente, a tirania. Ocupando os dois extremos do melhor e do pior, respectivamente, reino e tirania, as outras formas de constituição ocupam o espaço intermediário entre elas: reino, aristocracia, politia, democracia, oligarquia e tirania ${ }^{51}$. Sendo a pior entre as melhores e a melhor entre as piores, politia e democracia, respectivamente, constituem o menor desvio entre as formas corretas e as formas corrompidas. Daí, portanto, a confusão no momento de denominá-las ${ }^{52}$.

\footnotetext{
48 ARISTÓTELES, Politica, 1278 b 8 - 10.

49 ARISTÓTELES, Politica, 1279 a $25-31$.

50 ARISTÓTELES, Politica, 1279 a 31 - 1279 b 10; ARISTÓTELES, Ethica Nicomachea, 1160 a 31 - 1160 b 21. Essa tipologia das várias formas de governo não negligencia, todavia, os detalhes da complexa realidade histórica do mundo grego, reduzindo-a a um esquema rígido, ao qual aquela realidade teria de forçosamente adaptar-se, vd., por exemplo, BOBBIO (1980), p. 51s.

51 ARISTÓTELES, Politica, 1289 a 38 - 1289 b 4.

52 BOBBIO (1980), p. 50.
} 
Mais grave do que a distorção do julgamento moral individual é a perversão do julgamento moral coletivo, pois, nela, o Estado é posto a serviço de interesses que não se propõem a efetivar a obra especificamente humana. Todas as constituições eticamente reprováveis não promovem a vida virtuosa e feliz, da qual o Estado é simultaneamente realizador e defensor, já que a tarefa do político ou estadista (ó Tо入ıтıкó) não pode descurar as atividades da alma, pois ele deve estabelecer leis que favoreçam o pleno desenvolvimento de suas atividades ${ }^{53}$. No contexto de suas reflexões sobre as excelências morais, Aristóteles aponta para a tarefa dos legisladores

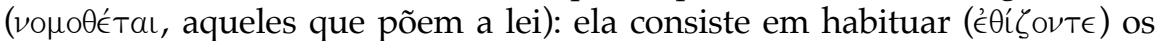
cidadãos a praticar boas ações, característica da boa constituição, pois a falha nesta tarefa acarreta o surgimento da má constituição ${ }^{54}$. A comunidade política, nos casos das formas corruptas de governo, perde sua razão de ser e só por homonímia, como costuma dizer Aristóteles, ainda recebe o nome de Estado, pois a palavra "Estado" tornou-se destituída da densidade ética por ela possuída nas formas corretas da constituição política. A distorção do julgamento moral pelas más formas de constituição dificulta a efetivação de uma comunidade política digna da forma racional humana.

O que, então, impediria ou dificultaria a transformação das constituições, de tal forma que os bons governos possuíssem estabilidade e maior resistência a passar para suas respectivas formas degeneradas? A resposta nos remete novamente à tese do meio-termo, já examinada por ocasião das virtudes ou excelências éticas.

A melhor comunidade política é aquela que consegue fugir dos extremos da riqueza e pobreza e constitui uma sociedade em que a maioria de seus cidadãos pertence à classe média, porque, nessa condição, a obediência à razão se torna mais fácil, assim como, analogamente, a alma sensitiva, fugindo dos extremos da deficiência e do excesso, alcança a justa medida da excelência moral graças ao papel de determinação da alma racional. Assim como Aristóteles já havia dito na Ética a Nicômacos: embora a virtude seja uma qualidade da alma, a vida corpórea e material pode empanar a realização de uma vida virtuosa, as condições materiais adversas desfavorecem a concretização da finalidade a ser implementada pelo Estado.

\footnotetext{
${ }^{53}$ ARISTÓTELES, Ethica Nicomachea, 1102 a 16 - 25. Estadista é a tradução de Mário Kury. No contexto, Aristóteles reforça a felicidade como uma atividade da alma, não do corpo. Daí, portanto, a necessidade de o político ou estadista ter algum conhecimento da alma.

${ }^{54}$ ARISTÓTELES, Ethica Nicomachea, 1103 b $2-6$.
} 
Em primeiro lugar, Aristóteles retoma o papel racional da mediania na determinação de uma vida virtuosa:

"Se, pois, é verdadeiro o que foi dito nos livros sobre a Ética, a saber, que a vida feliz é a vida de acordo com a virtude, sem impedimentos, e que a virtude é o meio-termo, então, é necessário que o meio-termo seja a melhor vida, uma mediania tal como é para ser alcançada por cada indivíduo" ${ }^{\prime 55}$.

Em segundo lugar, o argumento da vida virtuosa segunda a mediania é expandido para o âmbito das cidades e da constituição, formando, pois, um laço ético-ôntico entre o indivíduo e a polis: "É necessário que essas mesmas determinações da virtude e do vício sejam também as do Estado e da constituição, pois a constituição é uma certa vida do Estado" ${ }^{\prime 56}$.

Feita a articulação da virtude nos planos individual e coletivo segundo a lógica do justo-meio, então, em terceiro lugar, a mediania na dimensão política guarda uma estreita relação com a posse de riqueza, pois uma distribuição razoavelmente equilibrada da riqueza favorece uma vida coletiva em obediência à razão, à forma especificamente humana de ser e viver:

"Em todos Estados há três classes: os excessivamente ricos, os excessivamente pobres e uma terceira classe intermediária entre as duas primeiras. Já que é admitido que a justa medida e o meio-termo são o melhor, então, é evidente que a posse moderada dos bens da fortuna é a melhor de todas as posses. Pois, então, é mais fácil obedecer à razão, já que uma pessoa excessivamente bela ou excessivamente forte ou muito bem nascida ou excessivamente rica, ou, em caso oposto, excessivamente pobre ou excessivamente fraca ou bastante desonrada dificilmente acompanhará a razão" ${ }^{\prime 57}$.

Em quarto lugar, a importância dessa classe intermediária entre o excesso e carência de riqueza reside precisamente no fato de que ela proporciona as melhores bases materiais (os bens exteriores da Ética a Nicômacos) para consolidar uma forma correta de governo capaz de maior resistência ao desgaste do tempo. A classe média exerce, portanto, na dimensão política um papel análogo à virtude ética no plano individual. Ela oferece o locus mais favorável para a efetivação de uma vida conforme à razão, portanto, conforme à "obra do homem":

“É evidente, portanto, que a melhor comunidade política é constituída pelas camadas intermediárias entre ricos e pobres. É admitido que são bem governados os Estados nos quais a classe média é ampla e mais forte, antes de mais nada do que as duas outras em conjunto, ou pelo menos do que uma

\footnotetext{
55 ARISTÓTELES, Politica, 1295 a 35 - 39.

56 ARISTÓTELES, Politica, 1295 a 39 - 1295 b 1.

57 ARISTÓTELES, Politica, 1295 b 1 - 9.
} 
delas. Na medida em que seu peso é levado em consideração, ela promove equilíbrio e impede posições extremistas opostas" ${ }^{\prime \prime 8}$.

Não é de se estranhar, portanto, que o discernimento moral dos cidadãos tenha seu pleno florescimento nas condições de uma posse moderada de riqueza, tal como essa posse deve ser obtida nas circunstâncias específicas de uma comunidade política.

Finalmente, em quinto lugar, a sociedade em que predomina a classe média é a mais estável, assim como o homem virtuoso também o é, pois "onde é numerosa a classe média, há menos chance de surgir facções sediciosas e desavenças entre os cidadãos" ${ }^{\prime 59}$.

Bobbio $^{60}$ analisa o papel da politia como elemento mediador, de meiotermo entre os extremos da riqueza e da pobreza e, portanto, como forma mista de constituição que promove um alto grau de estabilidade. Para além do esquema abstrato no qual ela e as outras formas de governo são apresentadas, ele observa que Aristóteles pensa a politia como uma mistura entre democracia e oligarquia, pois essa mistura alcança um equilíbrio entre o mau governo dos poucos ricos (oligarquia) e o mau governo dos muitos pobres (democracia). Portanto, duas formas más de governo podem resultar em uma forma boa: "Dito de um modo simples, a politia é uma mistura $\left(\mu i \xi_{\iota}\right)$ de oligarquia e democracia ${ }^{61 "}$ ". E uma mistura que pode resistir, de uma forma melhor, à usura do tempo, pois ela consegue equilibrar as exigências de ricos e pobres: "Na maioria das cidades a forma da politia é aclamada, pois somente a mistura visa os ricos e os pobres, a riqueza e a liberdade ${ }^{62 "}$.

A tese do meio-termo entre extremos parece ser a tradução ética de uma tese platônica sobre o ser como resultado da determinação ou limitação da Díade Indeterminada ou do grande e do pequeno (o que corresponde à matéria no sentido de Aristóteles) pelo Uno (análogo à forma no sentido de Aristóteles): a oscilação para o menos e o mais é limitada pelo Uno ${ }^{63}$. A bipolaridade formada pelo par Uno e Díade Indeterminada configura todos os níveis do ser inteligível, bem como todos os planos do ser sensível, plasmando, com isso, todas as esferas do ser. Naquele há o predomínio do Uno sobre a Díade, de tal forma que "ali" reinam a estabilidade e a constância, ao passo que, neste, a Díade não está totalmente dominada pelo Uno, de tal modo que as realidades sensíveis estão submetidas a um

\footnotetext{
58 ARISTÓTELES, Politica, 1295 b $34-39$.

59 ARISTÓTELES, Politica, 1296 a 8s.

${ }^{60}$ BOBBIO (1980), p. 52 - 54.

61 ARISTÓTELES, Politica, 1293 b, 33 - 34 .

62 ARISTÓTELES, Politica, 1294 a 15 - 17

${ }^{63}$ KRÄMER (1994), p. 228, sublinha especificamente a referência da virtude moral como meio-termo e a constituição mista às instâncias axiológicas da tradição indireta.
} 
constante devir ${ }^{64}$. Não por acaso uma tal tese metafísica é aproveitada por Aristóteles no âmbito (1) das virtudes éticas como a justa medida, para nós, entre carência e excesso, (2) do papel estabilizador da classe média, enquanto ela configura uma posse moderada de riqueza que favorece o desabrochar das virtudes, e (3) da forma de governo da politia como mistura entre democracia e oligarquia. A sombra da ontologia de Platão não deixa de acompanhar, sob uma forma ou outra, as reflexões de Aristóteles.

Ora, se esse é o caso, a saber, se a não domesticação da Díade Indeterminada pelo Uno plasma a esfera do mundo sensível, então as formas de governo também não poderão resistir às inevitáveis degenerações ${ }^{65}$. Pois, mais cedo ou mais tarde, uma forma determinada de constituição, seja ela boa, seja ela má, dará lugar a uma outra forma, e assim por diante. Nesse contexto, o papel da politia como mistura entre democracia e oligarquia não consiste em impedir sua destruição, mas em retardar o movimento inexorável de sua transformação. Pois, se a mistura produz mais estabilidade, não consegue, porém, estancar o fluxo das mudanças. A maior estabilidade da politia adia "o quando" da mudança, não o seu "se".

Assim como o homem dotado de excelência moral alcança estabilidade e tranquilidade em suas ações, justamente porque não é mais arrastado pelas oscilações do mais e do menos, e, em virtude disso, seu julgamento moral obtém o equilíbrio de uma vida racional, de modo análogo a comunidade política em que a classe média constitui a maioria da população proporciona as melhores condições para o desenvolvimento moral, já que ela pode melhor enfrentar as extravagâncias dos ricos e as carências dos pobres. Não é por acaso, portanto, que a vida moral que cresce nessas condições alcance uma evolução mais fecunda do que aquela que tem lugar em sociedades em que os excessos da riqueza e as deficiências da pobreza tenham o predomínio. Os excessos promovidos pela riqueza e as carências provocadas pela pobreza favorecem um certo modo de vida - tanto mais legitimado por uma forma corrompida de constituição - que recorrentemente transgride os justos limites da sã razão. Em tal situação, a justa medida do meio-termo racional é enfraquecida pela força desagregadora dos extremos.

Embora a virtude seja uma qualidade da alma e não do corpo, o próprio Aristóteles reconhece que as condições materiais podem empanar o desabrochar das virtudes. Na vida da comunidade política isso não é menos evidente, e é tanto mais grave porque, como disse Aristóteles, a constituição é "uma certa vida dos Estados": toda a vida política, a saber, ética é

${ }^{64}$ REALE (1997), p. 471; vd. tb. GAISER (1998), p. 89 - 99.

${ }_{65}$ As degenerações das formas de governo têm lugar tanto na sucessão contínua de formas boas e más (de Aristóteles a Políbio) quanto na sucessão das formas más somente (Platão), BOBBIO (1980), p. 38. 
contaminada por uma ordem constitucional que desfavorece o desabrochar das virtudes.

Se, com efeito, o Estado é, por um lado, locus de nossa realização moral coletiva - mesmo levando em conta as limitações do pensamento de Aristóteles, ainda incapaz, por exemplo, de reconhecer a imoralidade da escravidão -, por outro, pode ser também fautor de nossa maior perversão ética. Nesse sentido, o Estado é o exemplo político da Díade Indeterminada. A teoria aristotélica chama atenção, assim, para o contexto político do desenvolvimento de nosso julgamento moral. Ele deve, pois, ter lugar em uma vida constitucional que, apoiada em razoável distribuição de riqueza, nos coloque a serviço do que é "a obra do homem" no seio da comunidade política que visa o interesse comum.

\section{Referências Bibliográficas}

ARISTOTE. L'Éthique à Nicomaque (Introdução, tradução e comentário de René A. Gauthier e Jean Y. Jolif). Louvain: Publication Universitaires, 1970 (4 vols.).

ARISTÓTELES. Ética a Nicômacos. Trad. de Mário da Gama Kury. $3^{\text {a }}$. ed. Brasília: Editora da Universidade de Brasília, 1992.

. De Anima. Apresentação, tradução e notas de Maria Cecília Gomes dos Reis. São Paulo: Ed. 34, 2006.

. Metafísica (Ensaio introdutório, texto grego com tradução e comentário de Giovanni Reale; tradução para o português de Marcelo Perine). São Paulo: Loyola, 2002.

ARISTOTELIS. Politica (recognovit brevique adnotatione critica instruxit W. D. Ross). Oxonii: E Typographeo Clarendoniano, 1957. (Scriptorum classicorum bibliotheca Oxoniensis).

Ethica Nicomachea (recognovit brevique adnotatione critica instruxit

I. Bywater). Oxonii: Clarendoniano, 1949. (Scriptorum classicorum bibliotheca oxoniensis).

De anima (recognovit brevique adnotatione critica instruxit W. D. Ross). Oxford: Oxford Univ., 1956. (Scriptorum classicorum bibliotheca Oxoniensis).

BOBBIO, N. A teoria das formas de governo. Brasília: Ed. Univ. de Brasília, 1980. (Pensamento Político, 17).

GAISER, K. Platons Ungeschriebene Lehre. Studien zur systematischen und geschichtlichen Begründung der Wissenschaften in der Platonischen Schule. Stuttgart: Klett-Cotta, ${ }^{3} 1998$.

HEGEL, G. Grundlinien der Philosophie des Rechts. Frankfurt/M: Suhrkamp, 1991. (Werke 7).

KERSTING, W. Die politische Philosophie des Gesellschaftsvertrags. Darmstadt: Wissenschaftliche Buchgesellschaft, 1994. 
KRÄMER, H. J. Platone e $i$ fondamenti della metafisica: saggio sulla teoria dei principi e sulle dottrine non scritte di Platone con una raccolta dei documenti fondamentali in edizione bilingue e bibliog. 5. ed. Milano: Vita e Pensiero, 1994.

KULLMANN, W. Theoretische und politische Lebensform (X 6-9), p. $253-276$, In: HÖFFE, O. (Hrsg.). Aristoteles, die Nikomachische Ethik. Berlin: Akademie Verlag. 1995. (Klassiker Auslegen; Bd. 2).

REALE, G. História da filosofia antiga. Trad. de Marcelo Perine. São Paulo: Loyola, 1993. (Vol. I).

História da filosofia antiga. Trad. de Henrique C. de Lima Vaz e Marcelo Perine. São Paulo: Loyola, 1994. (Vol. II).

Para uma nova interpretação de Platão: releitura da metafísica dos grandes diálogos à luz das "Doutrinas não-escritas". Tradução: Marcelo Perine. São Paulo: Loyola, 1997.

(Vol. I).

Aristóteles Metafísica. Ensaio introdutório. São Paulo: Loyola, 2001.

VIEIRA, L. Freiheit als Kultus. Aporien und Grenzen der menschlichen Freiheit bei Hegel. Würzburg: Königshausen \& Neumann, 1996.

WILBER, K. Integral Psychology, in: WILBER, K. The collected works of Ken Wilber. Boston: Shambhala, 1999. (Vol. 4).

WOLF, U. Über den Sinn der Aristotelischen Mesotheslehre, p. 83-108, In: HÖFFE, O. (Hrsg.). Aristoteles, die Nikomachische Ethik. Berlin: Akademie Verlag. 1995. (Klassiker Auslegen; Bd. 2).

ZINGANO, M. (Org.). A Ética de Aristóteles e o destino da ontologia. In: Analytica, vol. 1, número 3, 1996.

Razão e sensação em Aristóteles: um ensaio sobre De Anima III, 45. Porto Alegre: L\&PM, 1998.

Endereço do Autor:

R. Antônio Dias, 301/201

30350-150 Belo Horizonte - MG

leonarva@terra.com.br 